\title{
tripleC-Interview with Kerem Schamberger about Occupational Bans, Left-Wing Communication Studies and Critique of German Academia
}

\begin{abstract}
Kerem Schamberger is a doctoral student at the Ludwig Maximilian University of Munich's Department of Communication Studies and Media Research. He is also a left-wing activist and member of the German Communist Party (DKP). In the course of his appointment, the Bavarian Office for the Protection of the Constitution (Verfassungsschutz), based on Bavarian legislation, assessed whether Kerem should be considered as being a threat to the constitution and whether he should be denied employment. In German media sociology, there was a comparable case in the 1970s when an occupational ban was carried out against Horst Holzer. tripleC interviewed Kerem and asked him to explain the background in more detail.
\end{abstract}

Christian Fuchs and Thomas Allmer conducted the interview in German and translated it into English.

tripleC: Kerem, can you talk about your academic interests, the kind of research you are doing and are interested to conduct, and the political importance of these topics.

Kerem: My research focus is on the analysis of media systems, media freedom and journalists' autonomy. It is in this context important to go beyond the purely liberal understanding of press freedom. Many NGOs and partly also communication studies scholars hold such a liberal view. They see the state and potential state intervention as the primary threat to the independence of journalists and the media. This threat is indeed real, but many indexes of press freedom such as IREX or the Press Freedom Index disregard other important limits on media freedom. Market-liberal approaches constitute a blind spot in respect to property. The concentration of media ownership and the resulting restrictions of media freedom are often not taken into account. Sapiezynska and Lagos (2010) analysed the media freedom indexes by Freedom House and Reporters Without Borders. They concluded that these approaches are in the analysis of democratic countries incomplete because they concentrate on constraints and threats imposed by the state on journalists and miss out on drawing attention to the economic restrictions posed by structures of media ownership or dependencies on the advertising market. It is telling that Western organisations that focus on media freedom often arrive at very similar results although they use different approaches and methods. This results in a typical picture on the world map of press freedom: There is a high level of freedom in the "West", and a low one in the rest of the world. The issue of what negative roles the concentration of media ownership plays is not broached.

I conducted research on this topic in Uganda during the past year. It became evident that in Uganda it is less direct state intervention that restricts media freedom, the important factors are rather the poor working conditions in the media industry as well as the media owners' political and economic interests.

I also focus on discourse analysis. I am interested in what is said and what remains unsaid in our society and in how discourses make things become real.

tripleC: In how far do you see yourself in the tradition of critical media and communication studies? In how far do you consider yourself as a critical scholar? 
Kerem: I consider myself to be a critical communication studies scholar. This means first and foremost the focus on the Marxian analysis of society and the application of critical political economy in the realm of communication studies. But there is still a discrepancy between my demand and reality. There is no approach that is critical in this sense of the term at our Department in Munich as well as in German communication studies in general. The bachelor degree does not give space and time for an engagement with "marginal" theories in addition to the official teaching repertoire. In the master's degrees, what one learns depends very much on the professors' research interests. Although my studies have thus far really been fun, I have thus far not been able to familiarise myself more with Marxist communication studies. This approach fortunately exists for example in the UK and the USA, and also in Russia and India.

In Germany, scholars, who identified themselves as Marxists, have in the past politically and structurally been consequently pushed out of the universities. And junior scientists in this tradition could then also not gain ground.

At a whole I am missing the engagement with grand theories of society, including Marxism and others, in the field of media and communication studies. Scholars rather focus on mid-range theories and try to attain reputation by accumulating numbers. I consider these approaches as insufficient, especially in light of the development that society as a whole takes at the moment. Academia in general, including media and communication studies, should set itself the task of critically interrogating society and coming up with appropriate suggestions for solutions.

One of my goals is that I familiarise myself step-by-step with the critical part of communication studies. And fortunately I get support in this endeavour. For example by Thomas Allmer from the University of Stirling, with whom together I will next semester organise a seminar on the theme of "social media and capitalism".

tripleC: Can you also talk about your political life and how you became a political person? What personal experiences influenced you?

Kerem: I have been politically active since the age of 15 . Back then I read a lot, also the classics such as Marx, Engels and Lenin. I think the trigger was Che Guevara's biography that my father gave to me as a birthday present. I then thought that something must be done against the world's injustice. But this entails organisation and that one stands up together with others instead of isolated work. As a consequence, I became a member of Socialist German Workers Youth (SDAJ) in December 2001.

Around 2003 I joined the German Communist Party (DKP). I was especially interested in the combination of Marxist theory and concrete praxis. It is not a secret that the DKP is a pretty overaged party. But this poses the advantage that it has gathered lots of experience in social struggles from the time of German Nazi-fascism, the era of Adenauer and the time of rearmament. This fact still impresses me today. I certainly see our own history and the current development of my party very critically. We must confront the communist movement's crimes, work through them and learn from them for today. I think that not-yet all in the DKP have understood this issue. My political praxis takes more place outside of the DKP. Before I commenced my studies, I had been trained as management assistant in event organisation. I was a member of the work council. As a student I was active in the student union. I am also at times active in several civil society organisations. Since recently I have been dealing with the horrible developments in Turkey. One aspect of this interest is that one part of my family comes from this country. 
tripleC: After you had been offered a PhD position in media and communication research at the Ludwig Maximilian University of Munich (LMU), a legal procedure that could result in an occupational ban (Berufsverbot) commenced. Can you talk more about the background? How were you notified? What charges have been made? Who has initiated this procedure? What do you think are the underlying motives for it? What is the current situation?

Kerem: In July 2016, I applied to a position as research assistant supervised by Professor Meyen. When I got the job offer I had to complete the "Questionnaire for Assessing Constitutional Loyalty" (Bogen zur Prüfung der Verfassungstreue) that lists organisations that are, according to the opinion of the Bavarian Office for the Protection of the Constitution, anti-constitutional. All applicants applying to public service positions in Bavaria have to complete this Orwellian questionnaire. It is a scandal that the list contains anti-fascist organisations such as the Union of Persecutees of the Nazi Regime (Vereinigung der Verfolgten des Naziregimes) right next to Nazi organisations such as National Democratic Party of Germany (NPD) or militant, fascist fraternities. The list also contains left-wing organisations critical of capitalism such as the DKP or Red Aid (Rote Hilfe). So if you check that you are the member of such an organisation, then the Office for the Protection of the Constitution is asked for information on the background of the applicant. That is also what happened in my case.

The authorities did not get back to the university for months. This is why I could not take up my position on 1 October 2016. So this resulted in a de-facto occupational ban. The social-democratic Chancellor Brandt introduced the occupational bans in the early 1970s. They resulted in ten thousands of proceedings taken out against communists, peace activists and other leftists. Hundred thousands of people had to undergo examinations of their conscience. Occupational bans were abolished or have no longer been executed in most of Germany's federal states after 1989. But the situation in Bavaria is different. Bavaria has since the crushing of the Council Republic in 1919 been Germany's centre of right-wing politics.

In light of the Office for the Protection of the Constitution's waiting game, I decided to make the whole issue public. The former German federal minister of justice Herta Däubler-Gmelin, who today is a practicing attorney, supported me. There was a huge response in the media. The newspapers wrote about it and there was even a long television report. It is quite ironic that the Office for the Protection of the Constitution's inaction resulted in the presence of a communist on the newspapers' front pages and a new public engagement with the whole topic ${ }^{1}$. The Office for the Protection of the Constitution made a miscalculation. Finally it had to react and forwarded its "knowledge" about me to the university. The office concluded: "His advocacy of the

\footnotetext{
${ }^{1}$ Media coverage:

http://www.sueddeutsche.de/muenchen/trotz-einschaetzung-des-verfassungsschutzes-kommunistdarf-an-muenchner-universitaet-arbeiten-1.3308728

http://www.sueddeutsche.de/muenchen/kein-job-fuer-kommunisten-ein-hauch-von-kaltem-krieg-wehtdurch-die-Imu-1.3214909

http://www.sueddeutsche.de/muenchen/trotz-einschaetzung-des-verfassungsschutzes-kommunistdarf-an-muenchner-universitaet-arbeiten-1.3308728

http://www.eldiario.es/internacional/Kerem Schamberger-Universidad-Alemania-

comunista 0 572542875.html

http://operamundi.uol.com.br/conteudo/geral/45558/aluno+de+doutorado+e+impedido+de+dar+aulas+ em+universidade+da+alemanha+por+ser+comunista.shtml

http://sendika14.org/2016/11/alman-demokrasisi-naziler-devlete-solcular-disari-saffet-soylu
} 
Marxist doctrine and his self-definition as communist are actually not compatible with the Federal Republic of Germany's free democratic basic order". So it is clear that the "protectors" of the constitution, who are blind on the right political eye, react almost allergically to everything that has a left-wing character and do not want to see me working at the university.

Based on the Office for the Protection of the Constitution's insights the university asked me to answer five questions. I responded together with my lawyer. Around Christmas I received the response that the doubts about my loyalty to the constitution had been cleared and that I could take up the academic position on 1 January 2017. This is of course a huge success that could not have been achieved without all the solidary declarations and public pressure. I want to thank all those who supported me!

tripleC: Can you tell us which political institutions you listed as being a member of in your application? What could have happened if you had withheld any political affiliations in your application form?

Kerem: I checked association with the German Communist Party (Deutsche Kommunistische Partei, DKP), the Union of Persecutees of the Nazi Regime - Association of Antifascists (Vereinigung der Verfolgten des Naziregimes - Bund der AntifaschistInnen, VVN), Red Help (Rote Hilfe), and the Socialist German Workers Youth (Sozialistische deutsche Arbeiterjugend, SDAJ), where I was a member until 2013. Practically speaking, most people do not indicate their membership in such organisations because they know that they can then face problems. Then the Office for the Protection of the Constitution also does not conduct a check. But the public in Munich and Bavaria associates my name with the DKP. Since 2010, I have been one of the DKP's two speakers in Munich. And there was a larger scandal in 2014 when Commerzbank cancelled my mother's bank account because of her son being a communist. The media reported and so my name was associated with the DKP ${ }^{2}$.

tripleC: How have the University of Munich and its different departments (both in administration and research) reacted to the investigation against you? Do you think the university has an interest in this case at all? In how far has the university used its means in order to defend you in particular and academic freedom in general? Do you feel rather supported or rather neglected? Are you aware of other people at your university who are confronted with similar problems at the moment or faced such problems in the past?

Kerem: The Department of Communication Studies and Media Research, where I was supposed to be employed, and especially Professor Michael Meyen, have always been supportive. They have known me since my time of being a bachelor student. I have never hidden my political attitude, nor have I hawked around with it. Everyone has to decide that for him/herself. I am not able to assess exactly the position of the university's management. I am sure they are glad that this story has come to an end. But it is very courageous to decide against a recommendation from a security authority. The so-called Office for the Protection of the Constitution's efforts have always been directed against left-wing and progressive ideas. This office is traditionally blind on its right eye. Occupational bans for leftists have become rare, but they

\footnotetext{
${ }^{2}$ http://www.sueddeutsche.de/muenchen/konto-bei-der-commerzbank-kuendigungsgrund-sohn1.1874422
} 
are still effective as Sword of Damocles to discipline critical thoughts. The Bavarian state thus does not abolish the occupational bans. We are facing unsettled times. Such an instrument has always been very useful from the perspective of the rulers.

tripleC: Most of our readers will not be aware of the history of occupational bans in Germany. Can you talk a bit about their origin and history? How many people have been affected by it in Germany and in Bavaria? Do we know how many academics working in universities have over the decades been affected? Weren't the occupational bans abolished some time ago? What is the situation today? How exactly does the legal situation look like in Bavaria? Is it different in other German federal states? And if so, why? If you had for example been offered a PhD position in Berlin, could the same situation have happened there?

Kerem: Around 3.5 million civil service applicants were checked, which resulted in 11.000 official occupational bans. 1250 applications were rejected for that reason. 265 people were made redundant. Most of these cases happened in the 70 s and $80 \mathrm{~s}$ and, as I mentioned earlier, they have taken place less and less since 1989, but there are exceptions. In 2004, an occupational ban was carried out against an antifascist teacher in Baden-Württemberg. After he had gone through all the courts, he got his rights in 2007. The Questionnaire for Assessing Constitutional Loyalty still exists in Bavaria and Saxony. If I had wanted to do my PhD in Berlin, my DKP membership would probably not have led to any discussion. But there is now a new case in Berlin: The academic Andrej Holm lost his university job because it was claimed that he had provided incorrect information in respect to membership in the Stasi before 1989. He is one of the best academics in respect to the analysis of the development of the city in capitalism and has had major influence on discussions of gentrification. It is now important to show solidarity with him.

tripleC: There is a list of organisations that the Bavarian federal state considers to have an anti-constitutional character. Included are the German Communist Party DKP and the student organisation of the German Left Party (Die Linke.SDS). Are we right that also Die Linke as an entire party was until some point of time part of that list? Practically speaking this means that a member of such groups cannot find employment in any public service in Bavaria. What is the reasoning behind including such groups on this list? Democratic socialism is a fairly popular idea today, as for example the relative success of Bernie Sanders in the USA and Jeremy Corbyn in the UK shows. Do the positions of the DKP and Die Linke.SDS in your view substantially differ from Sanders or Corbyn or do they stand for a comparable concept of democratic socialism?

Kerem: The party Die Linke is since May 2016 no longer on the list of the supposed enemies of the constitution, which was really overdue. But organisations, which are closely related to Die Linke, such as the socialist student organisation SDS or the Left-Wing Youth (Linksjugend), are still listed, which is scandalous. I was just recently approached by a member of these organisations, because similar problems occurred there in the civil service. We stay tuned in such cases. Meanwhile, a Bavaria-wide Alliance against Espionage into People's Convictions was formed, where primarily trade unions are active. It argues for the abolition of the Questionnaire for Assessing Constitutional Loyalty in the civil service. 
Of course, the social movements that emerged around Bernie Sanders und Jeremy Corbyn and activists from the DKP and Die Linke.SDS have a lot in common. They share a critique of the existing capitalist society and the focus on the urgent need to build a new social order. Some would just like to reform capitalism and make it more humane, whereas others, including myself, think that capitalism as such cannot be made humane. It has to be replaced with a model based on economic and social solidarity. But even if some issues divide us, it is more important to seek a common ground. The Left cannot anymore afford to split and fight each other, neither in Germany, nor in the US or the UK. Concrete projects can and should be started and realised in the here and now. It always works this way.

tripleC: The German media and communication sociologist Horst Holzer was one of the most important representatives of an emerging German school of critical political economy of the media and communication. He was a member of the DKP. He faced an occupational job in 1971, which resulted in him being turned down for numerous professorships and being denied tenure at the University of Munich in 1974. How do you assess Horst Holzer's case? Which parallels can we draw between your and Holzer's case? What does it tell us that 45 years after Holzer's ban, critical scholars seem to still face the same problems in parts of Germany? In how far do you think are the underlying motives for such bans today similar/different to those in the 1970's?

Kerem: The occupational ban that was carried out against comrade Horst Holzer was far more drastic. He was an excellent scholar and theorist. I am a junior scholar starting to work on a PhD dissertation. It was and still is a scandal that Holzer was denied professorships. This case shows that Marxist scholarship was pushed out from the universities in Germany from a certain point in time onwards. For more information on this, I recommend the article by Scheu and Wiedemann (2008) that discusses the rejection of left-wing theories in German communication studies and presents Horst Holzer as an example.

tripleC: Most of our international readers will not know much about the political situation in Bavaria and Munich. Some may remember the Munich Council Republic of 1919, that the Nazi Party was founded in 1920 in Munich, and that Bavaria was the place, from where Hitler started his ascendancy to power. Can you talk a bit about the political situation in Bavaria today?

Kerem: The Christian Social Union (CSU) holds the absolute majority in the Bavarian parliament and still considers itself and Bavaria as Germany's "order cell" (Ordnungszelle) of Germany. It passed a so-called integration bill in 2016, where all immigrants are being sworn in to the "values and traditions of the Christian Occident" to the so-called "dominant culture". Bavaria is according to this bill shaped by "established traditions, customs and traditions" ${ }^{4}$. CSU-propagandists are proud to refer to rifle clubs from the mountains, who helped to shoot down the mentioned Council Republic. Christianity as alleged central part of a German culture is once more seen as central element of the constitution. The CSU's propaganda bridges a gap between the union of Christian Democratic Party (CDU)/CSU and the Alternative for Germany (AfD) and Pegida. The aim is to take the bread from the mouth of the so-called "right-

\footnotetext{
${ }^{3}$ http://www.vdj.de/uploads/media/160223_BaylntG_FassungMinisterrat.pdf

${ }^{4}$ lbid.
} 
wing populists" by taking over and amplifying their theses. The Bavarian governing party CSU moves the political elite to the right.

triplec: On the one hand, it is a very positive development that you could finally sign an employment contract around Christmas. But on the other hand this was not a Christmas gift, but just the confirmation of your legitimate right that you only attained after a public campaign. How do you assess the result and perspectives for the future of occupational bans against leftists in Bavaria? Could such cases repeat themselves?

Kerem: My employment at the University of Munich is of course a victory. It is not a present that I get this job, but my right. And it is really my Institute's right to decide whom they want to employ and whom not. Such issues should not be dealt with by the Office for the Protection of the Constitution. I think that the delay of the employment took such a long time because they had to reflect quite thoroughly: When I get employed, this creates a precedent for all universities in Bavaria. My political activities are fairly well known in Munich. Many people follow what we Marxists and communists organise. Also our events have been very well attended during the past months. In the future it will be even more difficult for the Office to use such delaying tactics in respect to progressive people. First, now everyone knows that such tactics result in a public outcry that harms the Office's reputation that is anyway already damaged. Second, one can now always refer to my case. When a member of the German Communist Party (DKP) can take up a funded doctoral position, then this should also be possible for an activist of the socialist student organisation SDS (Sozialistisch-demokratischer Studierendenverband) or an anti-fascist, who is organised in the Union of Persecutees of the Nazi Regime.

But in the meantime another left-wing activist has contacted me. In this case the issue is also employment as a public servant. It seems like this person will also get into troubles with the Office for the Protection of the Constitution. This circumstance shows that the whole issue has not disappeared by my employment. The so-called "Questionnaire for Assessing Constitutional Loyalty" (Bogen zur Prüfung der Verfassungstreue) has to be abolished. We have to continue this political struggle.

tripleC: Is it right that the Office for the Protection of the Constitution recommended to not employ you, but that the university took another decision? What are the legal foundations of this divergence? And do we know how the Office justified its argumentation?

Kerem: You have to savour that the Office for the Protection of the Constitution writes in its assessment that my engagement for Marxist thought and my selfdefinition as communist are not compatible with the Federal Republic of Germany's free democratic basic order. The broad hint that the underlying view is "Do no employ this enemy of the constitution" is quite evident here. At the moment, my lawyer checks whether I can publish the full text of the Office's assessment. I have nothing to hide. It becomes evident in this case how a German security agency tries to stigmatise critical humans.

It was a brave decision by the university to defy the Office for the Protection of the Constitution's recommendation. I have tremendous respect for this decision, especially because we today live in times where politics shifts towards the right. Legally speaking the university's decision is perfectly feasible because there is just a "rec- 
ommendation" that the university should adhere to the Office's insight. It is not compulsory that the university presents the entire Questionnaire for Assessing Constitutional Loyalty to applicants. Therefore now a discussion should start about changing the current practice so that the uncertainty created for the applicants comes to an end. The consequence could be that the questionnaire is no longer used in all Bavarian public service institutions.

tripleC: Leftists, who are affected by occupational bans, often do not go public because they fear further repression. Your case has resulted in a public debate. In Bavaria, an Alliance against Espionage into People's Convictions (Bündnis gegen Gesinnungsschnüffelei) has now been formed. Can you talk a bit more about this development?

Kerem: As I already mentioned earlier on, the political struggle against the Questionnaire for Assessing Constitutional Loyalty that has the role of a Sword of Damocles, is now of crucial importance. This is the goal of the new alliance. It is constituted by various union groups such as the Union for Education and Science Munich (Gewerkschaft für Erziehung und Wissenschaft München) or Ver.di Munich's section 5. But also Red Help (Rote Hilfe) and the DKP Munich participate. The Office for the Protection of the Constitution also has its eye on these two organisations. The alliance writes in its founding declaration: "The 'extremism list' stands in the tradition of the politics of the occupational bans. It is directed against social alternatives to the dominant economic and societal system. It tries to criminalise such approaches. The questionnaire has created an Orwellian atmosphere and the impression that oppositional democrats are prejudged to be enemies of the Bavarian state. The result is a climate of intimidation and uncertainty that is intensified by the disciplining of and the threats against single individuals. The consequence is a chilling effect on broad parts of trainees, students and teachers at schools and universities that can keep them from engaging in progressive politics and organising their interests" 5 .

This approach is completely right. The alliance's task is that it now utilises the momentum of the public and media discussion on the topic of the occupation bans in order to support institutions in abolishing the Orwellian conscience test.

tripleC: Thanks a lot for this interview. Please keep us informed about your future research.

\section{References}

Scheu, Andreas and Thomas Wiedemann, 2008. Kommunikationswissenschaft als Gesellschaftskritik. Die Ablehnung linker Theorien in der deutschen Kommunikationswissenschaft am Beispiel Horst Holzer. Medien \& Zeit 23 (4): 9-17.

Sapiezynska, Ewand and Claudio Lagos. 2016. Media Freedom Indexes in Democracies: A Critical Perspective Through the Cases of Poland and Chile. International Journal of Communication 10 549-570.

\section{Short biography Kerem Schamberger:}

2008-2011: Training as management assistant in event organisation and event manager;

\footnotetext{
${ }^{5}$ http://www.kerem-schamberger.de/2016/12/03/buendnis-gegen-gesinnungsschnueffelei-inmuenchen-gegruendet
} 
2011-2014: Undergraduate programme in media and communication studies, bachelor thesis on the German media's discourses on Cuba, internship at the newspaper Junge Welt;

2014-2016: Postgraduate programme in media and communication studies, MA thesis on media freedom in respect to elections in Uganda, recipient of a scholarship by the HansBöckler-Foundation, active in the communication studies-student union;

Since 2013: Work at the Institut für sozial-ökologische Wirtschaftsforschung (isw e.V.).

Since January 2017: research assistant in the group led by Prof. Michael Meyen at the LMU University of Munich; planned PhD dissertation topic: the Kurdish media system 